\title{
Examining Personal and Social Responsibility Levels of Secondary School Students
}

\author{
Selçuk Buğdayci \\ Faculty of Sports Sciences, Selçuk University, Konya
}

Copyright $(2019$ by authors, all rights reserved. Authors agree that this article remains permanently open access under the terms of the Creative Commons Attribution License 4.0 International License

\begin{abstract}
This study is a descriptive research study, which was conducted to determine personal and social responsibility levels of secondary school students. The research group is comprised of 602 (285 females, 317 males) students who are studying at the state schools under the Directorate of National Education in Konya Province. In obtaining the research data, Personal and Social Responsibility Scale (PSRS) was used, which was adopted to Turkish society by Filiz and Demirhan [1]. In the analysis of the research data, SPSS 22.0 program, independent $t$ test and One Way ANOVA test were used. As the conclusion of the research, it was determined that, in general, the personal and social responsibility levels of the students were high, from "gender" variable point of view, female students had higher responsibility levels. From the "grade" variable point of view, the 5th and 6th grade students had higher responsibility levels compared to the $h$ and 8th grades, the ones with sport training experience had higher levels, and the students, whose physical education teachers were female, had higher levels of personal and social responsibility.
\end{abstract}

Keywords Secondary School, Personal-Social Responsibility

\section{Introduction}

The concept of responsibility has started to become an increasingly important phenomenon in our age. In this regard, educators think that, particularly starting from preschool period, there should be efforts to ensure that students have the sense of responsibility.

Responsibility is defined as the awareness of a person concerning his/her behaviors or any event in his/her realm of authority, or his/her undertaking the consequences of his/her behaviors and the events [2]. In another definition, responsibility was described as making selections, and accepting the consequences and effects of these selections [3].
According to Lickona [4], responsibility is defined as taking care of oneself and others, fulfilling our obligations, participating in the society, coping with pain, and building a better world.

Ryan and Bohlin [5] define responsibility as living with the consequences of our faults, decisions, and habits about fulfilling our tasks. Schessler [6] approaches it as one's fulfilling his/her tasks and his/her being accountable for his/her actions. According to Gough, McClosky, and Meehl [7], responsible individuals are disposed to accepting the consequences of their behaviors, they inspire confidence, and they demonstrate a sense of liability and loyalty to the group they belong to. According to another definition, it is the belief of having the real power that prevents or causes the subjective critical consequences. These consequences can be tangible (e.g. car crash) or moral (I have unacceptable thoughts, which shows that I am a bad person) [8].

Personal and social responsibility concept was firstly suggested in the 1970s in order to make a contribution to the character development of the high school students and to provide a solution for their aggressive behavior problem. Focusing on the positive values, the concept is a holistic notion developed to increase the personal and social responsibility levels of the young people. Hellison thinks that physical education and sports is an available setting for producing important values for the students to take responsibility for themselves and others. The model emphasizes teaching the behaviors that can contribute to a positive development of the lives of the students, sports, and physical activities through the values. In such a way that, according to the personal and social responsibility model, the life skills and values should not be taught separately, but should be given integrated in the physical activity [9].

People with personal responsibility are in demand and they are liked in their environments. It is known that these people with a sense of responsibility have more apparent objectives, they are more hardworking, less-postponing their works, displaying higher loyalty to their tasks, showing less anxiety, and displaying better performances 
$[10,11]$.

Toedter [12] defines the personal responsibility as the ability to consider himself/herself as the source of his/her life, and defines it as the individual, who makes selection about shaping his/her life. These individuals are the ones, who are aware of their roles in those selections. In an attempt to define the personal responsibility concept, the field becomes important, where we handle the personal responsibility. From the health point of view, personal responsibility is to adopt a healthy life-style (like doing exercises, being careful about the weight, and not smoking), and to be a good patient (to maintain the health controls, obeying the recommendations of the doctor, and using the emergency of the hospitals only in case of necessity) [13].

With its rich, wide, and complex scope of application, physical education classes are accepted to have an important role in imbuing the students with values necessary for life, a sense of fair play, sportive competition, coping with stress, and preparing the school-age-children for social and moral problems [14,15,16,17]. It is known that the sport fields are not only a play setting, but also the places, where exercise and practices are performed, discussions are held, and where unlimited opportunities are provided for intervention to imbue the students with some values by informal student behaviors and for the emergence of the personal and social responsibility features of the students [14]. In the studies conducted by Aksoy and Gürsel [18], after giving an education with personal and social responsibility model, it was reported that there was a positive change in the views and behaviors of the students about moral concepts such as fair play.

In this context, according to the curriculum of the physical education class, which was restructured in 2009 for the secondary schools of Turkey, the youth is expected to use certain values for the life such as responsibility and gentlemanship, solidarity, tolerance, love, respect, attaching importance to personal and social values, together with skills such as critical and creative thinking, problem solving, self-management, and entrepreneurship [19]. With reference to this point, in this study, it was aimed to determine the personal and social responsibility levels of the secondary school students, and it was attempted to reveal the effect of gender, grade, sports training experience, and physical education teachers on these behaviors.

\section{Material and Method}

This study is a descriptive research study, which is conducted to determine personal and social responsibility levels of secondary school students. The research group is comprised of 602 (285 females, 317 males) students, who are studying at the state schools under the Directorate of National Education in Konya Province. Personal characteristics of the research group are given on Table 1.
Table 1. Personal characteristics of the research group

\begin{tabular}{|c|c|c|c|}
\hline Variables & Groups & $\mathbf{n}$ & $\mathbf{\%}$ \\
\hline \multirow{2}{*}{ Gender } & Female & 285 & 47,3 \\
\cline { 2 - 4 } & Male & 317 & 52,7 \\
\hline \multirow{2}{*}{ Grade } & 5 th grade & 144 & 23,9 \\
\cline { 2 - 4 } & 6th grade & 160 & 26,6 \\
\cline { 2 - 4 } & 7 the grade & 132 & 21,9 \\
\cline { 2 - 4 } & 8th grade & 166 & 27,6 \\
\hline \multirow{2}{*}{ Sports Education Experience } & Yes & 289 & 48,0 \\
\hline \multirow{2}{*}{$\begin{array}{c}\text { Gender of the Physical } \\
\text { Education Teacher }\end{array}$} & Fo & 313 & 52,0 \\
\cline { 2 - 4 } & Male & 470 & 78,1 \\
\hline
\end{tabular}

Data Collection Tool: In obtaining the research data, Personal and Social Responsibility Questionnaire (PSRQ) was used, which was originally developed by Li Weidong, Paul M. Wright, Paul B. Rukavina, and Molly Pickering in 2008 [20], and which was adopted to Turkish society by Filiz and Demirhan [1] as "Bireysel ve Sosyal Sorumluluk Ölçeği (BSS-Ö) (Lit. Personal and Social Responsibility Scale.)". Comprising of 13 items, the scale was used as single factoral model. The reliability co-efficient of the single factoral scale was determined as .925 . The lowest possible score of the scale was 13 , while the highest was 78 . Filiz and Demirhan [1] stated that, in order to use the scale, it was sufficient to declare the reference.

In the application process of the scale, after explaining the objective and the importance of the study, the students were asked to answer in 15 minutes.

In the analysis of the research data, SPSS 22.0 program, independent $t$ test and One Way ANOVA test were used.

\section{Findings}

The mean values that the research group obtained from the personal and social responsibility questionnaire are shown on Table 2. Accordingly, the mean score obtained from the scale was determined as $69.10 \pm 6.14$.

Table 2. The mean values that the research group obtained from the scale

\begin{tabular}{|c|c|c|c|c|}
\hline $\mathbf{N}$ & Minimum & Maximum & Mean & Std. Deviation \\
\hline 602 & 47.00 & 75.00 & 69.10 & 6.14 \\
\hline
\end{tabular}

The comparison of the scores that the research group obtained from the scale for the gender, sports training experience, and gender of the physical education teacher variables are given on Table 3. According to this, it was determined that there were statistically significant differences among the groups for all of the variables $(\mathrm{p}<0.001)$. 
Table 3. Comparison of the scores that the research group obtained from the scale for the gender, sports training experience, and gender of the physical education teacher variables

\begin{tabular}{|c|c|c|c|c|c|c|}
\hline Variables & Groups & $\mathbf{n}$ & Mean & Sd. & $\mathbf{t}$ & $\mathbf{p}$ \\
\hline \multirow{2}{*}{ Gender } & Female & 285 & 71.8316 & 3.61136 & 11.389 & .000 \\
\cline { 2 - 6 } & Male & 317 & 66.6498 & 6.87458 & & \\
\hline Sports Training & Yes & 289 & 71.1557 & 4.15916 & 8.315 & .000 \\
\cline { 2 - 6 } Experience & No & 313 & 67.2077 & 7.01269 & & \\
\hline $\begin{array}{c}\text { Gender of the } \\
\text { Physical } \\
\text { Education } \\
\text { Teacher }\end{array}$ & Female & 132 & 72.4697 & 3.60119 & 7.444 & .000 \\
\cline { 2 - 6 } & Male & 470 & 68.1574 & 6.37364 & & \\
\hline
\end{tabular}

It was determined that female students had higher personal and social responsibility levels, the ones with a sport training experience had higher personal and social responsibility levels, and the students, whose physical education teachers were female, had higher levels of personal and social responsibility.

The comparison of the scores that the research group obtained from the scale concerning the grade variable is given on Table 4. There were statistically significant differences among the groups $(p<0.001)$. In order to determine the groups with differences in between, LSD test was conducted. Accordingly, it was determined that the 5 th and 6th grade students had higher personal and social responsibility levels compared to the 7 th and 8 th grade students.

Table 4. Comparison of the scores that the research group obtained from the scale concerning the grade variable

\begin{tabular}{|c|c|c|c|c|c|c|}
\hline & $\begin{array}{c}\text { Sum of } \\
\text { Squares }\end{array}$ & df & $\begin{array}{c}\text { Mean } \\
\text { Square }\end{array}$ & F & p & $\begin{array}{c}\text { Significant } \\
\text { Difference }\end{array}$ \\
\cline { 1 - 4 } $\begin{array}{c}\text { Between } \\
\text { Groups }\end{array}$ & 1669.971 & 3 & 556.657 & & & \\
\cline { 1 - 3 } $\begin{array}{c}\text { Within } \\
\text { Groups }\end{array}$ & 20997.644 & 598 & 35.113 & 15.853 & .000 & $\begin{array}{c}1-3 \\
2-3 \\
2-4\end{array}$ \\
\cline { 1 - 3 } Total & 22667.615 & 601 & & & & \\
\hline
\end{tabular}

Groups; 1.group 5th grade, 2.group 6th grade, 3.group 7 th grade, 4.group 8th grade

\section{Discussion}

In this study, which was conducted to determine the personal and social responsibility levels of the secondary school students, variables were considered such as gender, grade, gender of the physical education teacher, and sports training experience, and it was determined that there were statistically significant differences among the groups.

The mean score that the complete research group obtained from the scale was determined as 69.10 . Considering that the highest score of the scale was 78.00, it can be stated that, in general, the secondary school students, who participated in our study, had quite high personal and social responsibility levels.

From the gender point of view, it was observed that the personal and social responsibility levels of the female students were higher than the male students. Therefore, it can be stated that the personal and social responsibility behaviors of the secondary school female students are more positive compared to the male students. According to the findings of the study conducted by Kurt [21], the social responsibility levels of the female adolescents are higher compared those of the male adolescents. Similarly, it is reported in many studies that the females have higher personal and social responsibility levels compared to the males $[22,23,24]$.

It is reported that female children are more empathetic, sensitive, passive, malleable, helpful to others, and able to establish intimate relations, compared to the male children; while it is reported that the male children are more dominant, less responsible, less expressive about their feelings, more aggressive, and more brash compared to the female children [25].

Considering the sport training experience, it was observed that the personal and social responsibility scores of the ones with sports training experience were higher compared to the ones without any sports training experience. In this respect, it can be stated that receiving a sports training makes positive contributions to the personal and social responsibility behaviors.

In the study conducted on the university students by Bayraktar et al. [26], it was reported that the personal responsibility levels of the students, who were doing sports, were higher.

Considering the variable "gender of the physical education teacher", it was observed that the personal and social responsibility scores of the students with female physical education teachers were higher compared to the students with male teachers. This difference can be attributed to that the female teachers show higher tendency to personal and social responsibility behaviors. Şirin [27] reported that the teachers have a key role in acquisition of personal and social responsibility. In a study conducted by Naktiyok and Ersarı [28], the master-apprentice relationship was examined, and it was reported that the support of the master had a partial intermediary role on the relationship between personal responsibility and career development of the apprentice. Moreover, it was also reported that the support of the master to the apprentice was effective on the career development of the apprentice, and the personal responsibility of the apprentice was influential on his/her career development. The motive behind this was attributed to the fact that the apprentices, who were happy with the training of their masters, were more willing to fulfill their tasks.

Considering the variable "grade" that the students study, it was observed that the 5th and 6th grade students had higher scores of personal and social responsibility, compared to the 7 th and 8th grade ones. Therefore, it can be stated that the higher the grade of the secondary school students, the lower their personal and social responsibility scores will be. This situation can be explained by that the 
higher grade students are preparing for the high school entrance exams, thus, they focus on only one point, which causes a decrease in their personal and social responsibility behaviors. In a study conducted by Karabaş [29], it was reported that 2nd grade high school students had higher responsibility levels compared to the 3 rd grade high school students.

As the conclusion, it was determined that, in general, the personal and social responsibility levels of the students were high, from "gender" variable point of view female students had higher responsibility levels, from the "grade" variable point of view the 5th and 6th grade students had higher responsibility levels compared to the 7th and 8th grades, the ones with sport training experience had higher levels, and the students, whose physical education teachers were female, had higher levels of personal and social responsibility.

In summary, it could be said that personal and social responsibility level of secondary school students are on expected high level.

\section{REFERENCES}

[1] Filiz B, Demirhan G. (2015). Bireysel ve Sosyal Sorumluluk Ölçeğinin (BSS-Ö) Türk Diline Uyarlanma Çalışması. Hacettepe Spor Bilimleri Dergisi. 26(2):51-64.

[2] Glover, Jonathan. On Responsibility. New York: Humanities Press, 1970.

[3] Popkin, Michael. Active Parenting: Teaching, Cooperation and Responsibility. San Fransisco: Harper \& Row Publishers, 1987.

[4] Lickona T. (1991). Educating for Character: How Our Schools Can Respect and Responsibility. New York: Bantam Books.

[5] Ryan K, Bohlin KE. (1999). Building Character in our Schools. San Francisco, CA: Jossey-Bass.

[6] Schessler EJ. (2011). Adolescent Perceptions on the Meaning and Development of Personal Responsibility: A Phenomenological Study (Unpublished Doctoral Dissertation) Azusa Pacific Unıversıty, California.

[7] Gough H, McClosky H, Meehl P. (1952). A Personality Scale for Social Responsibility" Journal of Abnormal \& Social Psychology, 47(1):73-80.

[8] Rhéaume J, Ladouceur R, Freeston MH, Letarte H. (1995). Inflated Responsibility and Its Role in OCD-I. Validation of A Theoretical Definition of Responsibility. Behaviour Research and Therapy, 33, 159-169.

[9] Hellison D. Walsh D. (2002). Responsibility-based youth programs evaluation: Investigating the investigations. Quest, 54, 292-307.

[10] Schlenker BR, Britt TW, Pennington J, Murphy R, Doherty K. (1994). The triangle model of responsibility. Psychological review, 101(4): 632-652.
[11] Gürel, H. (2012). The mediating role of individual responsibility on the relationship between corporate responsibility - organızational citizenship behavior and the role of corporate responsibility conceptions and organizational identification as moderators. (Doktora Tezi).İstanbul: Marmara Üniversitesi (198).

[12] Toedter LS. (1981). Construction and Validation of A Scale to Measure Personal Responsibility. The University of Connecticut. Unpublished Doctoral Dissertation.

[13] Steinbrook, Robert. (2006). Imposing Personal Responsibility for Health. New England Journal of Medicine, 355(8), 753-756.

[14] Hellison, D. (2014). Fiziksel aktivite yoluyla bireysel ve sosyal sorumluluk öğretimi. (Çev: Bijen Filiz), Nobel akademik Yayıncılık, Ankara.

[15] Kirk, D. (2010). Physical education futures. London: Routledge.

[16] Laker, A. (2001). Developing personal, social and moral education through physical education. New York, Routledge Falmer.

[17] Pringle R. (2010). Finding pleasure in physical education: A critical examination of the educative value of positive movement affects. Quest, 62, 119-34.

[18] Aksoy GK, Gürsel F. (2017). Beden Eğitimi Dersinde Bireysel ve Sosyal Sorumluluk Modeli Uygulamas1: Bir Eylem Araştırması. Eğitim ve Bilim, 42(191): 415-431: DOI: 10.15390/EB. 2017. 7149.

[19] Milli Eğitim Bakanlığı. (2009). Ortaöğretim beden eğitimi dersi öğretim programı (9-12. Sınıflar). Ankara: Milli Eğitim Bakanlığı Yayınları.

[20] Li W, Wright PM, Rukavina P, Pickering M. (2008). Measuring students' perceptions of personal and social responsibility and its relationship to intrinsic motivation in urban physical education. Journal of Teaching in Physical Education, 27, 167-178.

[21] Kurt, E. (2001). Effects of Religiosity Traits and Social Responsibility Attitudes on Nonspmtaneous Helping Behavior in A Natural Disaster. Boğaziçi Üniversitesi, Sosyal Bilimler Enstitüsü. Yüksek Lisans Tezi.

[22] Berkowitz L, Lutterman K. (1968). The Traditional Socially Responsible Personality. Public Opinion Quarterly. 32: 169-185.

[23] Schopler J, Baterson N. (1965). The Power of Dependency. Journal of Personality and Social Psychology, 2: 247 - 254.

[24] Fite DM, Genest CW. (1991). Gender Differences In Foreign Policy Attitudes; A Longitudinal Analysis. American Political Quarterly, 18:492-412.

[25] Atkinson RL, Atkinson RC, Hilgard E. (1995). Psikolojiye Giriş, (Çev: Atakay K, Atakay M, Yavuz A.) İstanbul: Sosyal Yayınları.

[26] Bayraktar G, Tozoğlu E, Gülbahçe Ö, Öztürk ME, Gülbahçe A. (2016). Üniversite Öğrencilerinin Bireysel Sosyal Sorumluluk Düzeylerinin Spor ve Farklı Değişkenler Açısından İncelenmesi. International Refereed Academic Journal of Sports, Health and Medical Sciences. 18:77-88.

[27] Şirin H. (2005). Öğrencilerin Sosyal Sorumluluklarının 
Geliştirilmesinde Öğretmenlerin Rolü. Gazi Eğitim Fakültesi Dergisi, 25(1):300-316.

[28] Naktiyok A, Ersarı G. (2017). Çırağın Bireysel Sorumluluğu ile Kariyer Gelişimi Arasındaki İlişkide Ustanın Desteğinin Aracılık Etkisi. MCBÜ Sosyal Bilimler Dergisi, 15(4):1-23.

[29] Karataş F. (2001). Ergenlik dönemindeki gençlerde sosyal sorumluluk, demokratik düşünce ve başkalarını kabullenme değişkenleri arasındaki ilişkilerin incelenmesi. Ankara Üniversitesi Sosyal Bilimler Enstitüsü. Yüksek Lisans Tezi. 